\title{
Proximate composition and nutritional value of fish powder composition (FPC) from different dried SIS fishes in Bangladesh
}

\author{
Sarmin Akther ${ }^{1 \star}$, Md. Badrul Islam², Habibur Rahman ${ }^{1}$ and Abdus Salam Bhuiyan' \\ ${ }^{1}$ Fisheries research laboratory, Department of Zoology, University of Rajshahi. Bangladesh. \\ ${ }^{2}$ Drugs \&Toxins Research Division, BCSIR Labs. Rajshahi-6206. Bangladesh. \\ *Corresponded author. Email: sarminhamim@gmail.com
}

Copyright $@ 2018$ Akther et al. This article remains permanently open access under the terms of the Creative Commons Attribution License 4.0, which permits unrestricted use, distribution, and reproduction in any medium, provided the original work is properly cited.

Received 17th July, 2017; Accepted 18th December, 2017

\begin{abstract}
The biochemical compositions and nutritional value of Small Indigenous Species (SIS) fishes were analyzed using analytical techniques. Proximate composition of five dried fish species viz. Glossogobius giuris, Colisa fasciata, Puntius ticto, Eutropiichtheys vacha, Corica soborna and a group of mixed SIS fishes viz. Chanda nama, Chanda ranga, Amblypharyngodon mola, Mastacembelus pancalus, Xenentodon cancila were selected for preparation of powder (FPC) which can be preserved for a time period. The fishes were sun dried or oven-dried. Quality of the oven-dried fish was better than that of the sun-dried fish, but sun drying process is easy and can be used in large scale. The fish powder remained in good condition up 7 to 9 months at normal room temperature, but at $-18^{\circ} \mathrm{C}$ the powder was in good condition throughout the year. Highest quantity of powder from $1 \mathrm{~kg}$ of fish was obtained in C. soborna (25.80\%) and the lowest in G. giuris (11.72\%). Biochemical analysis showed that the maximum moisture are found was $14.28 \%$ in G.giuris and minimum was $12.05 \%$ in C. soborna. Maximum protein content was recorded in G. giuris (73.32\%) and minimum was $58.06 \%$ in mixed SIS fishes. The maximum fat content of selected dried fish was $23.63 \%$ in $C$. soborna and minimum was $1.29 \%$ in $E$. vacha. The maximum calcium content was found was $2.53 \%$ in $P$. ticto and minimum was $1.66 \%$ in G. giuris. Maximum phosphorus content was $2.93 \%$ in $C$. fasciata and minimum was $1.85 \%$ in some mixed fishes. Maximum iron content was found as $32.00 \mathrm{mg} / 100 \mathrm{~g}$ in mixed SIS fishes and minimum was found as $20.25 \mathrm{mg} / 100 \mathrm{~g}$ in $P$. ticto. The results indicate that SIS fishes has high nutritional value in terms of protein, fat, and minerals.
\end{abstract}

Key words: Biochemical analysis, dried SIS fish, fish powder, nutrient.

\section{INTRODUCTION}

Fish is an essential and irreplaceable food item in the rural Bangladeshi diet. Fish is inseparable part of the Bangladesh economy and it plays a vital role in nutritional balance as an important source of protein (Ahmed et al., 1993). Besides protein, fish is a good source of carbohydrate, fat, vitamin and mineral (Falls, 2012). The analysis of proximate composition (four basic constituents: water, protein, fat, ash (mineral)) of fish muscle/flesh is often referred to as 'proximate analysis'. Fish flesh contains of water (70 to $80 \%$ ), protein (20 to $30 \%$ ) and 2 to $12 \%$ of lipid (Ali et al., 2005). In terms of weight of food consumed, fish ranks third after rice and vegetables (Minkin et al., 1997; Hels et al., 2002). The protein content of fishes ranges from 14 to $18 \mathrm{~g} / 100 \mathrm{~g}$ raw edible parts (Darnoton Hill et al., 1988). From the last national survey in rural Bangladesh, the mean total protein intake was $48 \mathrm{~g} /$ person/day, of which fish contributed $3 \mathrm{~g}$ (Ahmad and Hassan, 1983). Besides protein source, SIS of fishes are also rich source of vitamins and minerals, which is often overlooked in developing countries (Hossain and Afroze, 1991; Roos et al., 2007). Dried fishes are also rich in other nutritional components (Basu and Gupta, 2004).

The Small Indigenous Species (SIS) of fishes in Bangladesh are generally considered to be those which grow to a length of approximately 5 to $15 \mathrm{~cm}$ at maturity (Felts et al., 1996). The SIS fishes have short life cycle and can grow in all types of inland water bodies. Because of 
overfishing in inland water bodies and habitat destruction, a number of small fishes are now under the threat of extinction. In Bangladesh, 143 freshwater fish species are categorized as small indigenous fishes. In the past, these fishes were abundant in the rivers, beels, canals, streams and ponds. So, presently there is an urgent need to conserve the SIS fish and to increase their production through proper management of the water bodies of Bangladesh.

Thilsted et al. (1997) and Roos et al. (2007) reported that vitamin $\mathrm{A}$, calcium, iron and zinc are present in commonly consumed small fish species of Bangladesh. Very high content of vitamin A (500 to $1500 \mu \mathrm{g} R \mathrm{R} / 100 \mathrm{~g}$ raw edible parts) are obtained from Dhela (Osteobrama cotio cotio), Darkina (Esomus danricus), mola and chanda (C. baculis) (Roos et al., 2003). The sun-dried SIS fishes contain up to 60 to $80 \%$ protein (Hoq, 2004). A good number of works on nutrient composition of freshwater fishes of Bangladesh have been done by different researchers (Gheyasuddin et al., 1979; Rubbi et al., 1987; Naser et al., 2007; Kamal et al., 2007; Majunder et al., 2011; Sabinaet al., 2011; Flowra et al., 2012; Begum and Minar, 2012; Mahfuj et al., 2012; Ali, 2014) but very little attention has been paid on the proximate composition of nutrients which are present in dried fishes or dry fish dust. The present work was aimed at estimating the nutritional value of the dried fish powder of some selected SIS fishes of the Bangladesh.

\section{MATERIALS AND METHODS}

\section{Used fish species}

Five small fish species: Glossogobius giuris, Colisa fasciata, Puntius ticto, Eutropiichtheys vacha, Corica soborna and a group of mixed SIS fishes viz Chanda nama, Chanda ranga, Amblypharyngodon mola, Mastacembelus pancalus, Xenentodon cancila were used in the experiment.

\section{Sample collection}

Samples were collected from different spots of river bank (The Padma) and fish landing centers of Rajshahi city, during the period from July 2009 to June 2012. After collection, the fishes were brought to the Fishers Research Laboratory, Department of Zoology, Rajshahi University. The fishes were washed carefully with tap water and the waste materials were discarded and washed again for the second time. Then, the fishes were separated depending on size, sun-dried between 4 to 7 days under fly nets. Using an electric blender, the dried fishes were then powdered (species wise) and kept in separate airtight glass with propel label.

\section{Experimental place}

The dried samples were taken to the Bangladesh Council for Scientific and Industrial Research (BCSIR) Laboratory, Rajshahi, for the biochemical analysis.

\section{Parameter estimation}

The following components were determined for assessment of biochemical composition of fish species:

\section{Proximate composition analysis}

Moisture content of the fishes were determined by automatic moisture analyzer No. MAC 50/NH, RADWAG at $1100 \mathrm{C}$. Quantitative determination of protein was extracted by Kjeldahl method using automatic nitrogen analyzer model No. P SELECTA, Spain. Fat was done following the methods described by Cocks and Van Rede (1966) and Mehlenbacher (1960).

\section{Mineral analysis}

Mineral analysis of fish sample was done according to the AOAC method (AOAC, 1990). Calcium and Iron was determined by AAS (Atomic Absorption Spectrophotometer), Model No. AA-6800 SHIMADZU (Japan). Phosphorus was determined by measuring calorimetrically using a Vis-Spectrophometer Model No. GENESYS TM 20, Thermospectronic, USA.

\section{Statistical analysis}

Statistical analysis was performed by using the SPSS (Statistical package for social science, evaluation version 16). Significance was assigned at the $0.05 \%$ level. The mean values also compared to see the significant difference through DMRT (Duncan Multiple Range Test). Data were presented as mean \pm SD.

\section{RESULTS AND DISCUSSION}

The results showed composition variation of protein, fat, moisture and minerals (calcium, phosphorus and iron) of dried fishes (Figures1a to 1f). The result indicated a wide variation in proximate composition depended on the species. Among the mineral contents, calcium was found to range from $1.66 \%$ in G. giuris to $2.53 \%$ in $P$. ticto. The higher amount of phosphorus was found in C. fasciata $(2.93 \%)$ and the lowest was found in mixed fishes (1.85\%). Maximum amount of iron was found in mixed fishes $(32.00$ $\mathrm{mg} / 100 \mathrm{~g})$ and least amount was found in P. ticto $(20.25$ $\mathrm{mg} / 100 \mathrm{~g})$. Moisture content was high in G. giuris (14.28\%) and low in $C$. soborna (12.05\%). The highest percent of protein was found in G. giuris (73.32\%) and lowest was found in $C$. fasciata $(57.76 \%)$. The fat content was maximum $(23.63 \%)$ in $C$. soborna and minimum was $(1.29 \%)$ in E. vacha. 


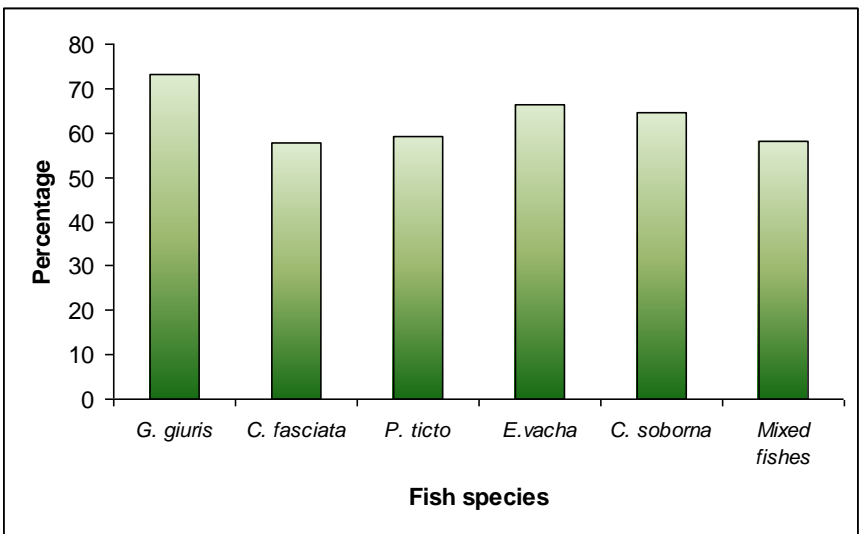

a

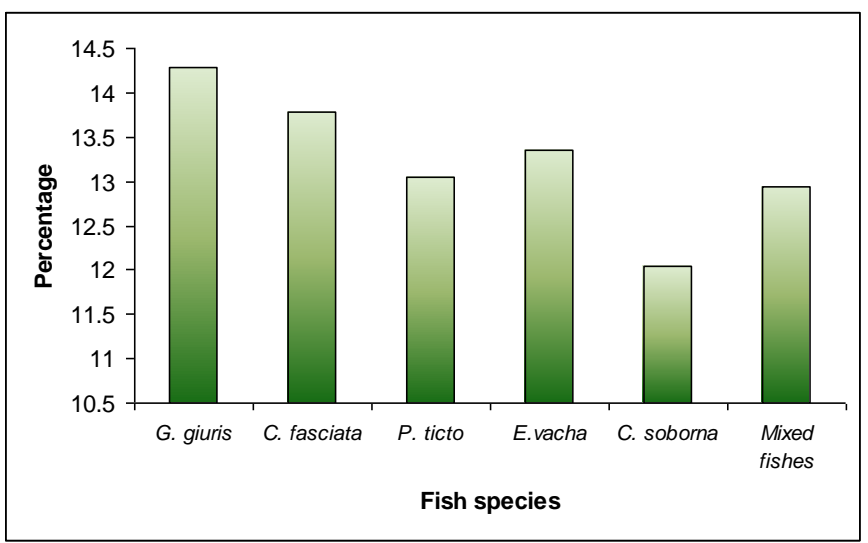

C

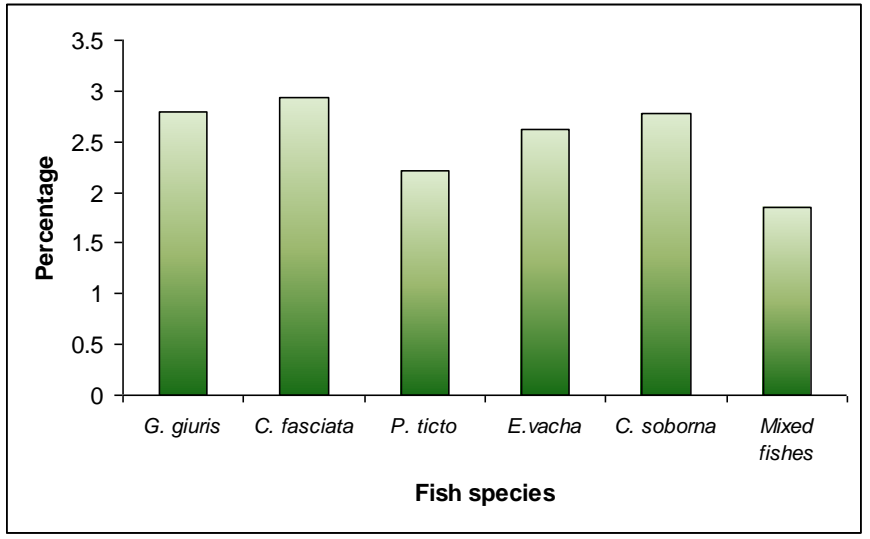

e

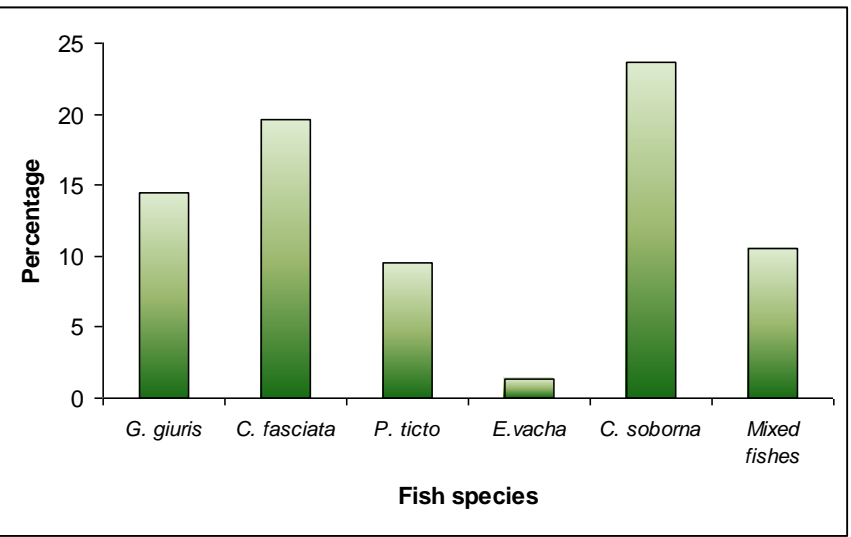

b

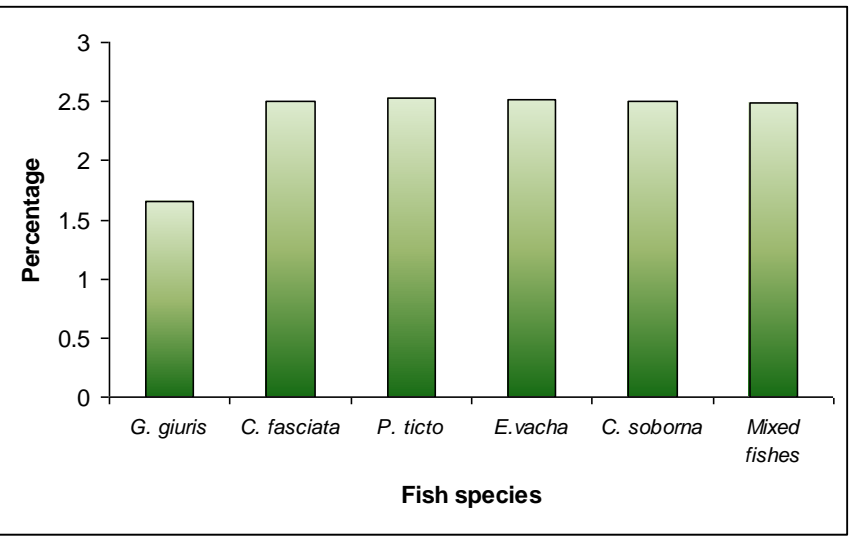

d

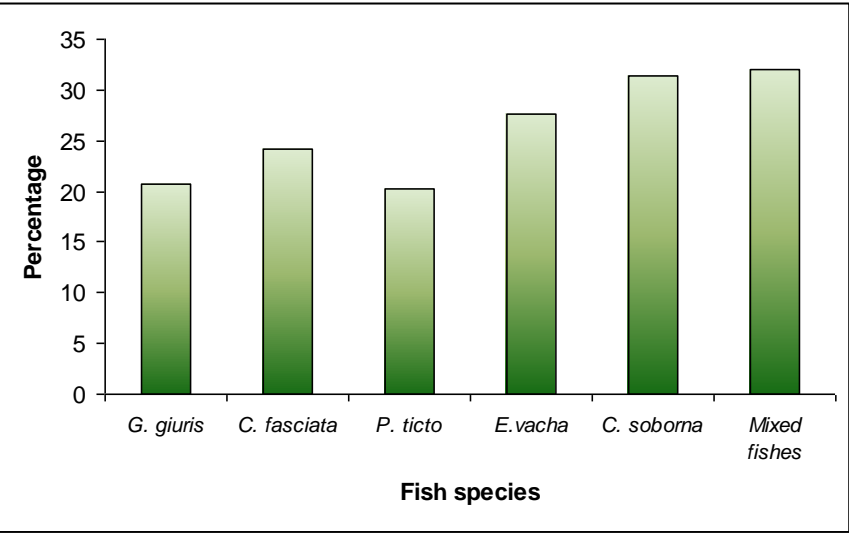

f

Figure1. Percentage of: a. protein; b. fat; c. moisture; $\mathbf{d}$. calcium; e. phosphorous; $\mathbf{f}$. iron of the studied small indigenous fish species (SISF).

The result revealed that $E$. vacha contained less fat and other species $C$. fasciata, $P$. ticto, $E$. vacha, $C$. soborna and mixed fishes were rich in calcium. Phosphorus was maximum in mixed fishes whereas iron was less in $P$. ticto compared to others. The percentage of moisture was also more or less same in all the experimental fishes.

According to the works of Kamal et al. (2007), Mazumder et al. (2008) and Musa (2009), the nutritional values of the 
small fishes are rich compared to the larger fish species. Similar findings reported by Sultana et al. (2011) for small indigenous fish species.

The biochemical composition (protein, fat, moisture, calcium, phosphorous and iron) of the dried fish powder were recorded. The analysis of nutrient composition shows that the dried small fishes used in the experiments are rich in protein containing 57.76 to $73.32 \%$. The percentages of fat ranged from 1.29 to $23.63 \%$. These dried fishes were also rich in iron and contain good amount of calcium and phosphorous. Calcium plays essential role in human body for the formation of bones, muscle tone and nervous impulse (Mollah et al., 1998). It has been reported that Cirrhina reba contains $822 \mathrm{mg}$ calcium $/ 100 \mathrm{~g}$ of fish (Islam et al., 2003). Species like Gudusia chapra, Channa punctatus and Amblypharyngodon mola contain 1063, 1093 and 1171 $\mathrm{mg} \mathrm{Ca} / 100 \mathrm{~g}$, respectively of raw edible parts (Roos et al., 2003). As SIS are consumed totally along with bones, so there is no wastage of calcium from these fishes. Phosphorous is another essential nutritional element for human, which is also present at a high percentage in the tested fishes.

\section{Moisture}

The moisture content of all living systems contributes as much to the essential properties of life. After drying, the moisture remained in the fish powder ranged from 12.05 to $14.28 \%$ in different species. The highest moisture content was found as $14.28 \%$ in dry G. giuris and the lowest was found as $12.05 \%$ in C. soborna. Azam et al. (2003) reported the range of fourteen selected dried fishes and observed that moisture content range from 18.23 to $23.61 \%$ which are more or less similar to the values obtained in the present study. However, Saha (1999) reported that sundried SIS fishes contained 36.50 to $82.80 \%$ moisture. Bhattacharyya et al. (1985) reported that sun-dried G. chapra contained 9.61 to $18.64 \%$ moisture. Nurullah et al. (2003) reported that moisture content ranged from 72.97 to $76.35 \%$ in six SIS fishes. The highest moisture content was recorded in G. chapra and the lowest in $P$. sarana. Hoq (2004) reported that sundried fishes contain an average of 10 to $20 \%$ moisture. Sabinaet al. (2011) also reported that moisture content of 7 dried fish species varied from 10.30 to $13.50 \%$. Flowra et al. (2012) reported the highest moisture content of $24.58 \%$ in $C$. soborna and lowest in $T$. haumela (14.06\%). The variation in moisture contents that was observed previous studies and present results might be due to amount of fat present in the species as fat content was inversely correlated with moisture contents.

\section{Protein}

Protein is the major nutrient in fish, and the levels help to define their nutritional status. Protein composition ranged from 57.76 to $73.32 \%$. G. giuris contained the highest percentage of protein $(73.32 \%)$. Among the tested fishes C. fasciata contain the lowest percentage of protein $(57.76 \%)$. Protein content varies among the species according to their food habit, amount of skeleton (Mazumder et al., 2008), size as well as expression of results such as dry weight basis/wet weight basis. Azam et al. (2003) found that the values ranged from 6.52 to $40.69 \%$ in 14 species of dried fishes. Hoq (2004) concluded that normally the sun-dried fishes contain 60 to $80 \%$ protein. Hussain et al., (1992) reported that protein content varied widely from 17.2 to $78 \%$ in 23 different dried species. Ali et al., (1992) found that the protein content of sun dried mola ranged from 59.6 to $61.2 \%$. Sabinaet al., (2011) reported that the protein content of 7 dried fishes ranged from 52.65 to $72.45 \%$. Flowra et al. (2012) also reported that the protein content of five dried fishes ranged from $44.08 \%$ (M. vittatus) and $65.65 \%$ ( $T$. haumela).

\section{Fat}

Fat content also varies greatly among the dried SIS fishes. Among the six experimental SIS fishes, fat content ranged from 1.29 to $23.63 \%$. The highest fat content was found in C. soborna as $23.63 \%$ and the lowest was $1.29 \%$ in $E$. vacha. Hussain et al. (1992) reported 3.7 to $17.8 \%$ fat content in 23 sundried fishes. Sabinaet al., (2011) also found the fat content of $C$. soborna which was $12.66 \%$. Begum and Minar (2012) reported fat content of $G$. chapraas $4.55 \%$. Dried Rita rita contains $13.72 \%$ lipid (Mollah et al., 1998) and Flowra et al., (2012) also reported dried $M$. vittatus contain $17.76 \%$ fat which are more or less similar to the present findings as fat was inversely correlated with moisture content.

\section{Iron}

In present experiment, six experimental dried fishes were found to contain iron ranging from $20.25 \mathrm{mg} / 100 \mathrm{~g}$ fish in $P$. ticto to $32.00 \mathrm{mg} / 100 \mathrm{~g}$ fish in mixed species. Nurullah et al. (2003) reported that iron ranged from 14.50 to 42.20 $\mathrm{mg} / 100 \mathrm{~g}$ of raw fish, and Chapila (G. chapra) contained the highest amount of iron among the studied small indigenous fish species (SIFS) which is somehow higher than the present studied results. Roos et al. (2003) reported that Esomus danricus was rich in iron (12 $\mathrm{mg} / 100 \mathrm{~g}$ fish) and among the other iron rich species were A. mola, G. chapra andM. vittatus. However, Roos et al. (2003) also indicated that the small fishes present in the fish culture ponds are low in iron and calcium, and NCR (Nutrient Contribution Ratio) value of these fishes were all low as $<5 \%$. The present findings more or less varied from the reported studies which may be attributed to lesser amount of skeleton (Mazumder et al., 2008), size as well 
as expression of results such as dry weight and basis/wet weight.

\section{Conclusion}

The results showed that dried or powdered SIS fishes are equally nutritive as they are in fresh condition. The Protein content was more than $50 \%$, with rich supply of iron, calcium and phosphorus (the essential minerals for human growth and life). These fishes can be sun dried and stored, and consumed for longer period. From these results, it can be concluded that dried SIS fishes, both fresh water and marine can provide nutritional security of the nation.

\section{ACKNOWLEDGEMENT}

The authors are highly grateful to Mr. Md. Badrul Islam, Senior Scientific officer, Drugs and Toxins Research Division, Bangladesh Council of Scientific and Industrial Research (BCSIR) Laboratories, Rajshahi, Bangladesh, Mr. Iftekhar Md. Noor and Md. Saiful Islam both are Instrumental Engineer, Central Science Laboratory, University of Rajshahi for their cordial co-operation and valuable help in bio-chemical analysis of the fishes.

\section{CONFLICT OF INTEREST}

The authors declare that they have no conflict of interest.

\section{REFERENCES}

Ahmad, K., \& Hassan, N. (1983). Nutritional survey of rural Bangladesh, 1981-82. Institute of Nutrition and Food Sciences. 2nd edn. University of Dhaka, Bangladesh.

Ahmed, M. M., Rab, A., \& Bimbao, M. P. (1993). Household socioeconomic resource use and fish marketing in two thanas of Bangladesh. ICLARM Tech. Rep., 40p.

Ali, A. (2014). Nutritional properties of some Novel Selected Fish Species in Khuzestan Province, IRAN. Journal of Food Technology Research, 1(2), 52-59.

Ali, M., lqbal, F. M., Salam, F., Sial, F., \& Athar, M. (2005). Comparative study of body composition of four fish species in relation to pond depth. Int. J. Environ sci. Tech., 2(3), 359-364

Ali, M.A., Hossain, M. A., \& Islam, M. A. (1992). A polythene tent dried for improved sun drying to fish (test varied out in Bangladesh). Bangladesh J. Training and Dev., 5(2), 25-32.

AOAC (1990). Official Methods of Analysis of the Association of official Agricultural chemist. 15th Ed. Vol 2. Association of official Analytical chemists. Inc. Wilson Boulevard, Arlington, virginia USA. Pp. 685-1298.

Azam, K., Basher, M. Z., Asaduzzaman, M., Hossain, M. H., \& Ali, M. Y. (2003). Biochemical quality assessment of fourteen selected dried fish. Univ. J. zool. Rajshahi Univ., 22, 23-26.

Basu, K. P., \& Gupta, K. (2004). Biological value of protein of some species of Bengal fish by balance and growth methods.
J. Indian. Chem. Soc. Calcutta, Pp. 543-548.

Begum, M., \& Minar, M. H. (2012). Comparative study about body composition of different SIS, Shell fish and llish commonly available in Bangladesh. Trends in fisheries research, 1(1), 3842.

Bhattacharyya, S. K., Vandyopadhway, J. K., \& Chattopadhyay, A. K. (1985). Improved dried product on blanching Gudusia chapra prior to sun drying. In: Harvest and post-harvest technology of fish. Society of Fish Technologists (India). p.531.

Cocks, L. V., \& Van Rede, C. (1966). Laboratory Handbook for oil and fats analysis. Academic press, London. 88p.

Darnoton-Hill, I., Hassan, N., Karim, R.,\& Duthie, M. R. (1988). Tables of nutrient composition of Bangladeshi foods. English version with particular emphasis on vitamin A content. Helen Keller International, Dhaka, Bangladesh.

Falls, M. (2012). Factors that Influence Food Access in the united States: A snapshot of food Access in Ohio and Kentucky, Maimouna Falls, Wright State University.

Felts, R. A., Rajts, F., \& Akhteruzzaman, M. (1996). Small Indigenous fish species culture in Bangladesh. IFADEP SubProject-2. Development of Inland Fisheries. 41p.

Flowra, F. A., Nahar, D. G., Tumpa, A. S., \& Islam, T. (2012). Biochemical analysis of five dried fish species of Bangladesh. Univ. J. Zool. Rajshahi Univ., 31, 9-11.

Gheyasuddin, S, Rahman, A., \& Mumtazuddin, M. (1979). Biochemical composition of shellfishes of Bangladesh. Bangladesh J. Sci. Res., 2, 15-23.

Hels, O., Hassan, N., Tetens, H., \& Thilsted, S. H. (2002). Food consumption energy and nutrient intake and nutritional status in rural Bangladesh: Changes from 1981-82 to 1995-96. Eur. J. Clon-Nutr., 57, 586-594.

Hoq, E. (2004). Bangladesher Chhoto Mach (A book on small indigenous fish species of Bangladesh). Publsihed by Graphic Sign, Mymensingh 2200. Pp. 81-84.

Hossain, M. A. \& Afroze, S. (1991). Small fisheries as resource in rural Bangladesh. Fishbyte. 9(2), 15-18.

Hussain, M. M., Karim, A., Alam, Z., Islam, M. S., Khan, A., \& Hossain, A. (1992). Effect of pre-treatment on the drying of ghonia fish Labeo gonius in the open sun and in a solar tent. Bangladesh J. Zool., 20, 231-238.

Islam, M. A., Mohsin, A. B. M., Bhuiyan A. S., \& Absar N. (2003). Biochemical composition and nutritional value of Cirrhina reba (Hamilton, 1822) of Bangladesh. J. Bio-Sci., 11, 127-130.

Kamal, D., Khan, A. N., Rahman, M. A., \& Ahamed, F. (2007). Biochemical composition of some small indigenous fresh water fishes from the river Mouri, Khaulna, Bangladesh. Pak. J. Bio. Sci., 10(9), 1559-1561.

Mahfuj, M. S., Hossain, M., Belal Hossain, M., \& Minar, M. H. (2012). Biochemical composition of and Endangered Fish, Labeo bata (Hamilton, 1822) from Bangladesh waters, American J. Food Tech. 7(10), 633-641.

Mazumder, M. S. A., Rahman, M. M., Ahmed, A. T. A., Begum, M., \& Hossain, M. A. (2008). Proximate composition of some small indigenous fish species in Bangladesh. Int. J. Sustain. Crop. Prod. 3(4), 18-23.

Mehlenbacher, V. C. (1960). Analysis of fat and oils. Garrard Press. Champaigh, Illinois. p. 586.

Minkin, S. E., Rahman, M. M., \& Halder, S. (1997). Fish biodiversity, human nutrition and environmental restoration in Bangladesh In: Openwater Fisheries of Bangladesh. Tsai, C., \& Ali, M. Y. eds. The University Press Limited. Dhaka, Bangladesh. Pp. 75-88

Mollah, A. H., Rahman, M. S., \& Alam, M. T. (1998). Study on proximate chemical analysis of Bangladeshi freshwater fish 
Rita rita (Ham.) and seasonal variation of Lipid, protein and related substances. Univ.Jj. Zoo., Rajshahi Univ., 17, 1-6.

Musa, A. S. M. (2009). Nutritional quality components of indigenous freshwater fish species, Puntiusstigma in Bangladesh. BangladeshJ. Sci. Ind. Res. 44(3), 367-370.

Naser, N. B., Chowdhury, G. W., Begum, M. M. \& Haque, W. (2007). Proximate composition of prawn, Macrobrachium rosenbergii and shrimp, Penaeus monodon. Dhaka Univ. J. Biol. Sci. 16(1), 61-66.

Nurullah, M., Kamal, M., Wahab, M. A., Islam, M. N., Ahsan, C. T., \& Thilsted, S. H., (2003). Nutritional quality of some small indigenous fish species of Bangladesh. In: Small indigenous species of fish in Bangladesh. Wahab, M. A., Thilsted, S. H., \& Hoq, M. E. eds. Bangladesh Agricultural University, Mymensingh. Pp. 151-158.

Roos, N, Islam, M. M., \& Thilsted, S. H. (2003). Animal source foods to improve micronutrient nutrition and human function in developing countries. J. Nutr. 133, 4021S-4026S.

Roos, N, Wahab, M. A., Chamnan, C., \& Thilsted, S. H., (2007). The role of fish in food-based strategies to combat vitamin $A$ and mineral deficiencies in developing countries. J. Nutr. 137, 1106-1109.
Rubbi, S. F., Mujibar, M., Khan, A. R., Jahan, S. S., \& Majeda, B. (1987). Proximate composition and quality of some commercial species of freshwater fish. Bangladesh J. Sci. Res., 5(1), 1-20.

Sabina, S., Selina, P., \& Hossain, M. A. (2011). Biochemical analysis of some dried SIS fishes of the river Padma in Rajshahi. J. Life Earth Sci., 6, 39-43.

Saha, S. C. (1999). Studies on production, marketing and nutritional aspects of traditional dried products of fresh water small indigenous fish species. MS thesis. Department of Fisheries Technology, Bangladesh Agricultual University, Mymensingh, 101p.

Thilsted, S. H., Roos, N., \& Hossain, N. (1997). The role of small indigenous fish species in food and nutrition security in Bangladesh. NAGA. The ICLARM Quarterly, July-December: 13-15. 